\title{
Directly mining a fungal thermostable a-amylase from Chinese Nong-flavor liquor starter
}

\author{
Zhuolin $\mathrm{Yi}^{1,2,3}$, Yang Fang ${ }^{2,3}$, Kaize He ${ }^{2,3}$, Dayu Liu' ${ }^{1}$, Huibo Luo ${ }^{4}$, Dong Zhao ${ }^{5}$, Hui He ${ }^{6}$, Yanling Jin ${ }^{2,3^{*}}$ \\ and Hai Zhao ${ }^{1,2,3 *}$ (1)
}

\begin{abstract}
Background: Chinese Nong-flavor (NF) liquor is continuously and stably produced by solid-state fermentation technology for 1000 years, resulting in enrichment of special microbial community and enzymes system in its starter. Based on traditional culture-dependent methods, these functional enzymes are hardly obtained. According to our previous metatranscriptomic analysis, which identifies plenty of thermostable carbohydrate-active enzymes in NF liquor starter, the aim of this study is to provide a direct and efficient way to mine these thermostable enzymes.
\end{abstract}

Results: In present study, an alpha-amylase (NFAmy13A) gene, which showed the highest expression level of enzymes in starch degradation at high temperature stage $\left(62^{\circ} \mathrm{C}\right)$, was directly obtained by functional metatranscriptomics from Chinese Nong-flavor liquor starter and expressed in Pichia pastoris. NFAmy13A had a typical signal peptide and shared the highest sequence identity of $64 \%$ with a-amylase from Aspergillus niger. The recombinant enzyme of NFAmy $13 \mathrm{~A}$ showed an optimal pH at 5.0-5.5 and optimal temperature at $60^{\circ} \mathrm{C}$. NFAmy $13 \mathrm{~A}$ was activated and stabilized by $\mathrm{Ca}^{2+}$, and its half-lives at 60 and $70^{\circ} \mathrm{C}$ were improved significantly from 1.5 and $0.4 \mathrm{~h}$ to 16 and $0.7 \mathrm{~h}$, respectively, in the presence of $10 \mathrm{mM} \mathrm{CaCl}_{2}$. Meanwhile, $\mathrm{Hg}^{2+}, \mathrm{Co}^{2+}$ and SDS largely inhibited its activity. NFAmy13A showed the maximum activity on amylopectin, followed by various starches, amylose, glycogen, and pullulan, and its specificity activity on amylopectin was $200.4 \mathrm{U} / \mathrm{mg}$. Moreover, this a-amylase efficiently hydrolyzed starches (from corn, wheat, and potato) at high concentrations up to $15 \mathrm{mg} / \mathrm{ml}$.

Conclusions: This study provides a direct way to mine active enzymes from man-made environment of NF liquor starter, by which a fungal thermostable a-amylase (NFAmy13A) is successfully obtained. The good characteristics of NFAmy $13 \mathrm{~A}$ in degrading starch at high temperature are consistent with its pivotal role in solid-state fermentation of NF liquor brewing. This work would stimulate mining more enzymes from NF liquor starter and studying their potentially synergistic roles in NF liquor brewing, thus paving the way toward the optimization of liquor production and improvement of liquor quality in future.

Keywords: Chinese Nong-flavor liquor starter, Thermostable, Fungal a-amylase, Starch degradation, Solid-state simultaneous saccharification and fermentation

\footnotetext{
*Correspondence: jinyl@cib.ac.cn; zhaohai@cib.ac.cn

${ }^{3}$ Environmental Microbiology Key Laboratory of Sichuan Province,

Chengdu Institute of Biology, Chinese Academy of Sciences, No. 9

Section 4, Renmin Nan Road, Chengdu 610041, Sichuan, People's

Republic of China

Full list of author information is available at the end of the article
} 


\section{Background}

Chinese liquor accounts for more than one-third of all spirits consumed in the world according to the International Wine and Spirit Research Group. Chinese liquor is produced by a solid-state simultaneous saccharification and fermentation (SSF) in an environment-friendly way for 1000 years, and Nong-flavor (NF, also called strong aroma type) liquor accounts for more than $70 \%$ of Chinese liquor production $[1,2]$. Its manufacture mainly contains two steps: 4 months of liquor starter (daqu) production and 40-45 days of alcohol solid-state fermentation [3,4]. Special and stable microbial communities are enriched during the NF liquor starter production process [5], and in the mature NF liquor starter [6]. These microbes would secret various enzymes, e.g., amylase, acid protease, cellulase, lipase, and esterase, to efficiently hydrolyze carbohydrates and proteins $[7,8]$.

Recently, great efforts have been made to mine enzymes by culture-independent method of metagenomics using either sequence-based or function-based screening from environmental systems, e.g. soil, rumen, ocean, spring, gut, activated sludge, skin surface, compost, most of which are from prokaryotic microbes [9]. And, it is still very difficult to obtain enzymes of eukaryotic microorganisms from environments, due to difficulties in extracting polyadenylated messenger RNA (metatranscriptomics), and the lack of efficient and compatible hosts. At present time, only a few enzymes are reported to be identified by functional metatranscriptomics of eukaryotes from soil, rumen and the gut of the termite [10-13], or by sequence-based metatranscriptomics of eukaryotes from forest soil [14]. Same as soil, eukaryotic microbial communities also play pivotal roles in man-made environmental NF liquor starter, since NF liquor starter is mainly made from wheat $[3,8]$. However, in a long time, the complicities in this man-made environment of NF liquor starter, e.g., the high content of starch and other polysaccharides, thousands of fermentation products at high temperature, limit the acquisition and characterization of active enzymes from this environment, and only crude enzymes are analyzed until now [7]. Recently, a breakthrough on NF liquor starter is made by metatranscriptomic analysis in our previous work, and it is found that fungi are the most abundant and active community members and total 932 carbohydrate-active enzymes are identified at the high temperature stage (N3) of $62{ }^{\circ} \mathrm{C}$ [3]. Moreover, many active enzymes with whole length gene sequences are identified. Therefore, metatranscriptomic analysis provides a direct and efficient sequence-based method to mine these fungal functional enzymes from NF liquor starter.

To verify the feasibility of this method, enzymes related to starch degradation are selected, since starch is the main composition of wheat material in NF liquor starter [8]. In the liquor starter, alpha-amylase makes the largest contribution to liquefaction of starch, and works efficiently with glucoamylase to produce fermentable reducing sugars $[4,8]$. And thermostable $\alpha$-amylases are more attractive in biotechnological processes, since they are stable over $60{ }^{\circ} \mathrm{C}$ and allow a higher operation temperature which result in higher reactivity, higher process yield, fewer contamination, and so on [15]. NF liquor starter is a promising resource for thermostable fungal $\alpha$-amylase, since its making process is subjected to high temperature (N3) of $62{ }^{\circ} \mathrm{C}$ for 8 days. Moreover, based on previous metatranscriptomics analysis of NF liquor starter, enzymes related to starch metabolism, e.g., $\alpha$-amylase, $\beta$-glucosidase and glucoamylase, showed relatively high expression level at high temperature stage (N3), and $\alpha$-amylases exhibited the second highest RPKM (Reads Per Kilobase per Million) value up to 465.7, which stands for the second highest expressional enzymes in N3 [3]. Therefore, thermostable $\alpha$-amylase is finally selected to be directly mined from NF liquor starter, which should have high efficiency in liquefaction of starch.

In the present study, we provided a direct and efficient way to mine enzymes from man-made environment of Chinese NF liquor starter, by which one fungal thermostable $\alpha$-amylase was successfully obtained and characterized. This $\alpha$-amylase was the highest expression enzymes related to starch hydrolysis at high temperature period $\left(62{ }^{\circ} \mathrm{C}\right)$, and showed interesting characteristics, such as $\mathrm{Ca}^{2+}$-dependent on activity and thermostability, high stability at $60{ }^{\circ} \mathrm{C}$, acidic $\mathrm{pH}$ optima at $5.0-5.5$, the more efficient hydrolysis on amylopectin than on amylose, high activity on starches and tolerances of high substrates concentrations $(15 \mathrm{mg} / \mathrm{ml})$. This study would shell light on understanding the important role of this thermostable $\alpha$-amylase in NF liquor starters and pave the way toward the optimization of liquor production and improvement of liquor quality. To the best of our knowledge, this is the first report of directly mining enzymes from NF liquor starter.

\section{Methods}

\section{Materials}

Escherichia coli DH5 $\alpha$ strain (Sangon Biotech, Shanghai) was used for gene cloning and plasmid maintenance throughout the study, and Pichia pastoris X33 strain (Invitrogen, Carlsbad, CA, USA) was used for protein expression. The pGAPZ $\alpha A$ vector (Invitrogen, Carlsbad, CA, USA) was used for gene cloning. Potato starch, wheat starch, corn starch, amylose (potato) and amylopectin (potato) were obtained from Sigma-Aldrich (St. Louis, $\mathrm{MO})$. The Mix (Green) for PCR amplification was from TsingKe (Beijing, China). The QIAprep Spin Miniprep 
Kit and RNeasy ${ }^{\circledR}$ Midi Kit were obtained from Qiagen (Valencia, CA). SMART ${ }^{\circledR}$ cDNA Library Construction Kit, Advantage ${ }^{\circledR} 2$ PCR Kit and the Talon metal affinity resin were purchased from Clontech Laboratories, Inc. (Mountain View, CA). The Amicon ${ }^{@}$ ultra centrifugal filters were obtained from Millipore (Billerica, MA). All other reagents were purchased from general commercial suppliers and used without further purification.

\section{Liquor starter sampling, RNA extraction and cDNA library construction}

NF liquor starter was sampled from a liquor fermentation factory in Yibing, Sichuan, China. As described in our previous work [3], sample N3 was collected after 9 days of liquor starter fermentation with temperature around $62{ }^{\circ} \mathrm{C}$. Briefly, samples were frozen in liquid nitrogen immediately after obtained in factory, transferred to $50 \mathrm{ml} \mathrm{RNase}$ free tubes and kept in dry ice. Finally, all samples were transferred to Chengdu Biology Institute, Chinese Academy of Sciences and stored at $-80{ }^{\circ} \mathrm{C}$ for further research.

A previously published protocol [3] was used to extract total RNA from liquor starter with some modifications. In short, $1 \mathrm{~g}$ of liquor starter was homogenized into fine powder in a precooled mortar. Next, $4 \mathrm{ml}$ borate buffer [200 mM sodium borate (pH 9.0), $30 \mathrm{mM}$ ethyleneglycoltetraacetic acid (EGTA), 1\% (w/v) sodium dodecyl sulfate (SDS), $4 \%(\mathrm{w} / \mathrm{v})$ polyvinylpyrrolidone (PVP), and $0.5 \%$ (v/v) Nonidet-40 (NP-40), $10 \mathrm{mM} \beta$-mercaptoethanol and $0.03 \%(\mathrm{v} / \mathrm{v})$ RNase inhibitor] and $280 \mu \mathrm{l}$ of proteinase $\mathrm{K}(20 \mathrm{mg} / \mathrm{ml})$ were mixed and incubated at room temperature for $2 \mathrm{~min}$. The RNA of this crude lysate was then centrifuged, precipitated with $70 \%$ ethanol, and cleaned according to the RNeasy Midi Kit protocol. An extra treatment with DNase I (Fermentas, USA) on RNA mixture was also performed according to the manufacturer's protocol.

Three microliters of total RNA (around $1 \mu \mathrm{g}$ ) was used as template for first-strand synthesis with MMLV Reverse Transcriptase, after which the cDNAs were amplified via 20 cycles of a long distance PCR (LD-PCR) using the $\mathrm{SMART}^{\circledR}{ }^{\circledR}$ CDNA Library Construction Kit. The resulting environmental cDNAs were used as template to specifically amplify $\alpha$-amylase gene sequence.

\section{Gene cloning, expression and protein purification}

The metatranscriptomics of liquor starter N3 was analyzed in our previous work. The gene product of ORF17558 was predictively composed of alpha-amylase domain and DUF1966 domain (DUF: domain of unknown function) (Fig. 1a), and it was designated NFAmy13A, since it is the first characterized alpha-amylase in Nong flavor liquor starter. The nucleotide sequence encoding the NFAmy13A was amplified with Mix (Green) using N3 cDNA as the template, with NFAf $5^{\prime}$ GGTACCGCG ACTCCGGATGAGTGGAAAGCTCAG3' and NFAr5' TCTAGACGCCGACGCACACAGACCACTCTTG3' primers containing $K p n \mathrm{I}$ and $\mathrm{Xba \textrm {I }}$ site, respectively. The PCR products and plasmid pGAPZaA (Invitrogen) were digested with KpnI and XbaI (New England Biolabs). The resulting DNA fragments were ligated with T4 DNA ligase (New England Biolabs) and the ligated product was transformed into E. coli DH5a. The transformants were selected on low salt $\mathrm{LB}(10 \mathrm{~g} / \mathrm{l}$ tryptone, $5 \mathrm{~g} / \mathrm{l} \mathrm{NaCl}$ and $5 \mathrm{~g} / \mathrm{l}$ yeast extract) agar plate supplemented with $25 \mu \mathrm{g} /$ $\mathrm{ml}$ zeocin (Sangon Biotech, Shanghai). Single colonies were inoculated into LB medium supplemented with same antibiotics, and cultured overnight. Plasmids were extracted (Qiagen mini-prep kit) from the cultures, and the inserts were verified by DNA sequencing (TsingKe, Chengdu, China).

The recombinant plasmid with correct insert (pGAPZaA/NFAmy13A) was linearized by Avr II and transformed into P. pastoris X33 using MicroPulser Electroporator (Bio-Rad Laboratories, Hercules, CA, USA) for gene expression. After 3 days incubation on YPD medium $(10 \mathrm{~g} / \mathrm{l}$ yeast extract, $20 \mathrm{~g} / \mathrm{l}$ peptone and $20 \mathrm{~g} / \mathrm{l}$ dextrose) supplemented with $1 \mathrm{M}$ sorbitol and $100 \mu \mathrm{g} /$ $\mathrm{ml}$ zeocin at $30{ }^{\circ} \mathrm{C}$, single colonies were inoculated into $25 \mathrm{ml}$ YPD medium with same concentrations of sorbitol and zeocin at $30^{\circ} \mathrm{C}$ with vigorous shaking at $250 \mathrm{rpm}$ for 2 days, and transformants with correct inserts were analyzed by PCR amplification with pGAP Forward (5'-GTC CCTATTTCAATCAATTGAA- $3^{\prime}$ ) and $3^{\prime}$ AOX (5'-GCA AATGGCATTCTGACATCC-3') primers according to Invitrogen protocol. The correct transformants were further verified by activity assays in supernatants after centrifugation at $6000 \mathrm{~g}$ for $5 \mathrm{~min}$ at $4{ }^{\circ} \mathrm{C}$.

The transformants with correct inserts were expressed in $500 \mathrm{ml}$ YPD medium supplemented with same amount of sorbitol and zeocin at $30{ }^{\circ} \mathrm{C}$ and $250 \mathrm{rpm}$ for 2 days. After centrifuge, supernatants were heated twice at $55^{\circ} \mathrm{C}$ for 15 min since proteins from N3 were expected to be thermostable, and the precipitated host proteins were pelleted by centrifugation at $12,000 \times g$ for $10 \mathrm{~min}$ at $4{ }^{\circ} \mathrm{C}$. Then, supernatants were filtered through $0.45 \mu \mathrm{m}$ MFMillipore membrane and adjusted to Tris- $\mathrm{HCl}$ buffer (pH 7.5, $50 \mathrm{mM}$ Tris- $\mathrm{HCl}, 300 \mathrm{mM} \mathrm{NaCl}$ ). The resulting supernatants were applied to the talon metal affinity resin and the recombinant proteins with $\mathrm{N}$-terminal 6-Histidine-tag were purified according to the manufacturer's instruction (Clontech). The bound proteins were eluted with the elution buffer ( $150 \mathrm{mM}$ imidazole, $50 \mathrm{mM}$ Tris- $\mathrm{HCl}, 300 \mathrm{mM} \mathrm{NaCl}, \mathrm{pH} 7.5)$, and the fractions were analyzed by sodium dodecyl sulfate-polyacrylamide gel electrophoresis (SDS-PAGE). The fractions containing 
a

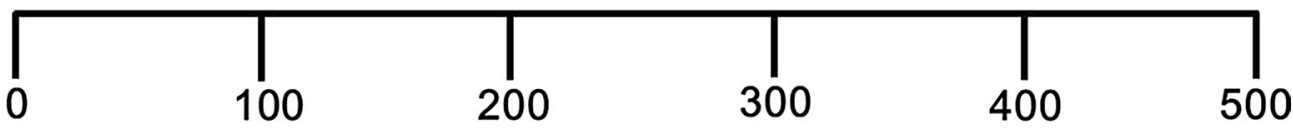

\section{Alpha-amylase (GH13) -DUF1966}

b
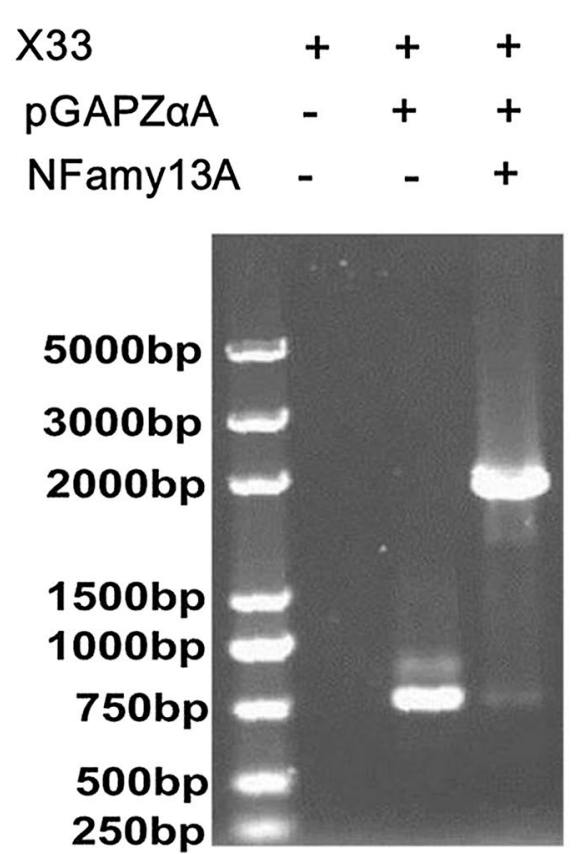

C

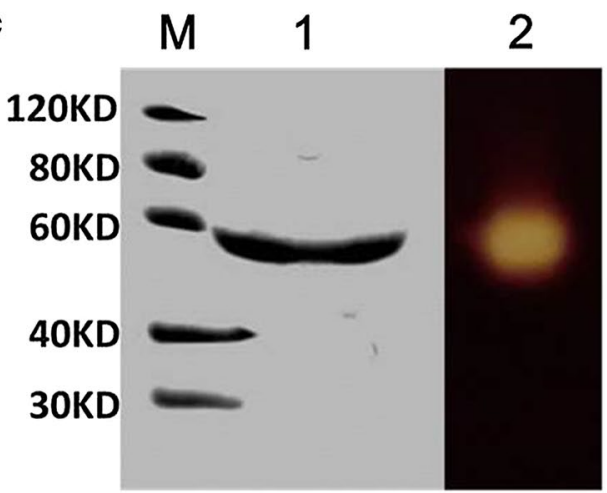

d

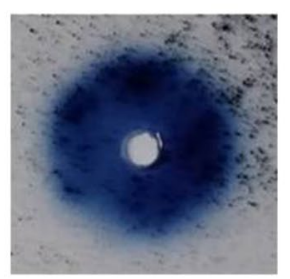

Fig. 1 Schematic representation, genomic integration, Zymogram analyses and plate-based activity assays of NFAmy13A. a Schematic representation of NFAmy13A. b Verification of integration of NFAmy13A gene into genome of P. pastoris X33. c Zymogram analyse of amylase activities of native NFAmy13A. $\mathbf{d}$ Plate-based activity assay of native NFAmy13A. The signal peptide is represented by the filled rectangle. GH13: family 13 glycoside hydrolase domain. GUF1966: domain of unknown function 1966. Lane M, molecular mass markers; Lane 1, purified native NFAmy13A; Lane 2, zymogram of purified native NFAmy13A

the purified NFAmy13A proteins were concentrated, the buffer of which was changed to a protein storage buffer (50 mM Tris- $\mathrm{HCl}, 150 \mathrm{mM} \mathrm{NaCl}, \mathrm{pH} 7.5$ ) with Amicon Ultra-10 centrifugal filters. The protein concentrations were measured using a NanoDrop 2000c (Thermo Fisher Scientific Inc., Waltham, MA) and the Beer-Lambert law with the extinction coefficients of $91,010 / \mathrm{M} / \mathrm{cm}$ for NFAmy13A.

\section{Zymogram analysis and plate-based activity assay of NFAmy13A}

For zymogram analysis, around $20 \mu \mathrm{g}$ purified NFAmy13A was loaded onto $10 \%$ native-PAGE gel (without SDS). After electrophoresis, the gel was washed with $50 \mathrm{mM}$ citrate buffer $(\mathrm{pH} \mathrm{5.5)}$ for three times. Then the gel was overlaid on a sheet containing $1 \%$ soluble starch with $1.5 \%$ agar and $0.01 \%$ Trypan Blue in $50 \mathrm{mM}$ citrate buffer ( $\mathrm{pH} \mathrm{5.5)} \mathrm{for} 1 \mathrm{~h}$ at $60{ }^{\circ} \mathrm{C}$. Finally, amylase activity was visualized as a clear zone by staining this sheet with Lugol's iodine solution.

For plate-based activity assay, around $20 \mu \mathrm{g}$ purified NFAmy13A was added onto the center hole of plate containing $0.1 \%$ AZCL-amylose (Megazyme) with $1 \%$ agarose in $50 \mathrm{mM}$ citrate buffer ( $\mathrm{pH} 5.5$ ), and the plate was kept at $60{ }^{\circ} \mathrm{C}$ for $2 \mathrm{~h}$. Then the amylase activity was visualized with blue zone around the hole.

\section{Enzyme assays}

The optimal $\mathrm{pH}$ of NFAmy13A was determined by incubating $40 \mathrm{nM}$ NFAmy13A with $5 \mathrm{mg} / \mathrm{ml}$ potato 
starch between pH 4.0 and 9.0 (50 mM citrate buffer for $\mathrm{pH} 4.0-6.0,50 \mathrm{mM}$ sodium phosphate buffer for $\mathrm{pH}$ 6.0-8.0, $50 \mathrm{mM}$ Tris- $\mathrm{HCl}$ for $\mathrm{pH} 8.0-9.0$ ) at $55^{\circ} \mathrm{C}$ for $30 \mathrm{~min}$. The reducing sugars released were measured using the para-hydroxybenzoic acid hydrazide ( $p \mathrm{HBAH}$, Sigma-Aldrich, St. Louis, MO) assay [16] with glucose as the standard. Meanwhile, the optimal temperature was determined by incubation of $40 \mathrm{nM}$ NFAmy13A and $5 \mathrm{mg} / \mathrm{ml}$ potato starch at its optimal $\mathrm{pH}$ at different temperatures ranging from 30 to $80{ }^{\circ} \mathrm{C}$ for $30 \mathrm{~min}$.

The specific activity of NFAmy13A was determined by incubating $20 \mathrm{nM}$ enzymes with $5 \mathrm{mg} / \mathrm{ml}$ potato starch at $60{ }^{\circ} \mathrm{C}$ and $\mathrm{pH} 5.5$ for different time intervals, within the range where the slopes of released glucose equivalents versus time were linear. One unit of alpha-amylase activity was defined as the quantity of enzyme capable of releasing $1 \mu \mathrm{mol}$ glucose equivalent per minute under its optimized conditions. The digestion of various substrates was also characterized by incubating $100 \mathrm{nM}$ NFAmy13A with $5 \mathrm{mg} / \mathrm{ml}$ substrates at $60^{\circ} \mathrm{C}$ and $\mathrm{pH} 5.5$ for $30 \mathrm{~min}$.

\section{Thermostability assay}

To determine the thermostability of NFAmy13A, enzymes $(80 \mathrm{nM})$ were incubated in a citrate buffer $(\mathrm{pH}$ $5.5)$ at 50,60 and $70{ }^{\circ} \mathrm{C}$ in THERMO SHAKER. Samples were taken out at different time points and placed on ice. The residual enzymatic activity was determined by incubating $40 \mathrm{nM}$ enzymes with $5 \mathrm{mg} / \mathrm{ml}$ amylopectin at $60{ }^{\circ} \mathrm{C}$ in a citrate buffer (pH 5.5) for $30 \mathrm{~min}$.

\section{Effect of metal salts and chemical additives on amylase activity}

The effect of various metal salts was studied by adding 1 and $10 \mathrm{mM}$ metal salts and additives to the reaction mixture of $100 \mathrm{nM}$ enzymes with $5 \mathrm{mg} / \mathrm{ml}$ amylopectin under standard assay. Relative activities were calculated as a percentage of the activity of the unadded control as $100 \%$.

\section{Kinetics hydrolysis of NFAmy $13 \mathrm{~A}$ on starch substrates}

The kinetics studies of NFAmy13A were determined by incubating purified NFAmy13A with different concentrations of starch substrates, i.e., amylopectin, amylose, potato starch, corn starch or wheat starch, ranging from 0.1 to $18 \mathrm{mg} / \mathrm{ml}$. The reducing ends were measured after incubation under normal condition for $30 \mathrm{~min}$ in the presence of $10 \mathrm{mM} \mathrm{CaCl}_{2}$, and the velocities were kept in a constant scope under every condition by using low concentration of $20 \mathrm{nM}$ enzyme.
Application of NFAmy13A in the hydrolysis of raw potato starch substrates

To measure the effect of concentrations of starch substrates, i.e., potato starch, corn starch or wheat starch, their concentrations were varied from 1 to $18 \mathrm{mg} / \mathrm{ml}$ in citrate buffer ( $\mathrm{pH} 5.5$ ) containing high concentration of $1 \mu \mathrm{M}$ enzymes and $10 \mathrm{mM} \mathrm{CaCl}$. After incubation at $60{ }^{\circ} \mathrm{C}$ for $20 \mathrm{~h}$, the concentration of reducing ends was estimated using the $p \mathrm{HBAH}$ assay as described above. Then, the end products was analyzed by thin-layer chromatography (TLC) with glucose (M1) and maltoseoligosaccharides (M2-M6) as standards and $n$-butanolacetic acid- $\mathrm{H}_{2} \mathrm{O}$ (10:5:1, vol/vol/vol) as developing mobile phase. The sugars were visualized by spraying with a $1: 1$ (vol/vol) mixture of methanolic orcinol $(0.2 \% \mathrm{wt} / \mathrm{vol})$ and sulfuric acid (20\% vol/vol) followed by heating at $100{ }^{\circ} \mathrm{C}$ for $5 \mathrm{~min}$ [17].

\section{Nucleotide sequence accession numbers}

The nucleotide sequence of NFAmy13A was deposited at the GenBank database with accession number MF765801.

\section{Results \\ RNA extraction and cDNA library construction}

Total RNA was extracted from $1 \mathrm{~g}$ of liquor starter sample N3 and approximately $15 \mu \mathrm{g}$ RNA was obtained with high purity. Full-length cDNA was synthesized by the initial reverse transcription and enriched by subsequent LD PCR. When analyzed by agarose gel, environmental double strands cDNA appeared as a strong smear ranging from $100 \mathrm{bp}$ to $4 \mathrm{~kb}$, and it was adequate for the subsequent specific amplification.

\section{Cloning, expression, and purification of NFAmy13A}

ORF17588 was identified to predictively encode an alpha-amylase, which was designated as NFAmy13A since it was the first characterized alpha-amylase in NF liquor starter. Based on our previous metatranscriptomics analyses of NF liquor starter, NFAmy13A was the only alpha-amylase in the top 20 highest expression level of glycoside hydrolases in N3 (Additional file 1: Table S1) with RPKM value of 293.5, and accounted for around 63\% of total alpha-amylases in N3 (Additional file 1: Table S2), thus being the highest expression level of alpha-amylases in starch degradation of N3. In addition, NFAmy13A also showed active expression with RPKM value of 30.9 in mature stage of NF liquor starter according to our previous metatranscriptomic analysis (Additional file 1: Table S2). The wheat material of NF liquor starter is rich in starch. Therefore, NFAmy13A could play a pivotal role 
in liquefaction of NF liquor starter at high temperature stage and mature stage, and it was characterized in present work.

The amino acid sequence of NFAmy13A was analyzed by the Pfam server (http://pfam.sanger.ac.uk/), and it had alpha-amylase domain and DUF1966 domain (Fig. 1a). The product of NFAmy13A gene had a signal peptide when predicted on SignalP 4.1 Server (http://www.cbs. dtu.dk/services/SignalP/) (Fig. 1a). The NFAmy13A gene sequence (1431 bp), without signal peptide sequence, was successfully obtained by specific amplification with primers NFAf/NFAr from ds cDNA of N3, and one colony with correct gene integration into genome of $P$. pastoris X33 was identified by PCR with primers pGAP Forward $/ 3^{\prime}$ AOX from three colonies (Fig. 1b). This colony showed the highest activity of $28.3 \mathrm{U} / \mathrm{ml}$ when cultured for $72 \mathrm{~h}$. NFAmy13A was purified to near homogeneity, and the apparent molecular masses of the purified recombinant NFAmy13A corresponded well with its calculated values (56.1 KD) (Fig. 1c). Obviously, purified NFAmy13A showed strong amylase activity in degrading starch in a native-PAGE gel (Fig. 1c) and an agarose plate (Fig. 1d), when analyzed with zymogram method and plate-based activity assays, respectively.

\section{Characterization of NFamy13A}

NFAmy13A from the highest temperature $\left(62{ }^{\circ} \mathrm{C}\right)$ stage $\mathrm{N} 3$, showed optimal activity at $60{ }^{\circ} \mathrm{C}$ and more than $80 \%$ of activity remaining between 45 and $65{ }^{\circ} \mathrm{C}$ (Fig. 2a), to some extent, which could support the efficient hydrolysis of starch by NFAmy13A at high temperature of
$62{ }^{\circ} \mathrm{C}$ in $\mathrm{NF}$ liquor starter. Maximum $\alpha$-amylase activity was observed at $\mathrm{pH}$ 5-5.5 for NFAmy13A, and there were still $50 \%$ of activity remaining between $\mathrm{pH} 4.5$ and 7.0 (Fig. 2b). Therefore, standard assays were performed at $\mathrm{pH} 5.5$ and $60{ }^{\circ} \mathrm{C}$ for $30 \mathrm{~min}$ throughout this work, except for special mentioned.

Furthermore, according to the hydrolysis result (Table 1), NFamy13A had higher activity on amylopectin

Table 1 The hydrolysis of various substrates catalyzed by NFAmy13A

\begin{tabular}{|c|c|c|}
\hline Substrate & Main linkage/monomer & Relative activity (\%) \\
\hline Amylopectin (potato) & $\begin{array}{l}a(1 \rightarrow 4)-a(1 \rightarrow 6) \\
\text { glucose }\end{array}$ & $100.0 \pm 4.9$ \\
\hline Amylose (potato) & $a(1 \rightarrow 4)$ glucose & $15.5 \pm 1.1$ \\
\hline Potato starch & $\begin{array}{l}a(1 \rightarrow 4)-a(1 \rightarrow 6) \\
\quad \text { glucose }\end{array}$ & $62.6 \pm 9.4$ \\
\hline Wheat starch & $\begin{array}{l}a(1 \rightarrow 4)-a(1 \rightarrow 6) \\
\text { glucose }\end{array}$ & $21.8 \pm 1.8$ \\
\hline Corn starch & $\begin{array}{l}a(1 \rightarrow 4)-a(1 \rightarrow 6) \\
\text { glucose }\end{array}$ & $30.7 \pm 1.6$ \\
\hline Maltodextrin & $a(1 \rightarrow 4)$ glucose & $18.9 \pm 1.9$ \\
\hline White dextrin (corn) & $\begin{array}{l}a(1 \rightarrow 4)-a(1 \rightarrow 6) \\
\text { glucose }\end{array}$ & $66.1 \pm 4.8$ \\
\hline Pullulan & $\begin{array}{l}a(1 \rightarrow 6)-a(1 \rightarrow 4) \\
\text { glucose }\end{array}$ & $2.3 \pm 1.5$ \\
\hline Dextran T500 & $\begin{array}{l}a(1 \rightarrow 6)-a(1 \rightarrow 3) \\
\quad \text { glucose }\end{array}$ & 0 \\
\hline Glycogen & $\begin{array}{l}a(1 \rightarrow 4)-a(1 \rightarrow 6) \\
\text { glucose }\end{array}$ & $11.2 \pm 0.6$ \\
\hline CMC & $\beta(1 \rightarrow 4)$ glucose & 0 \\
\hline Cellulose & $\beta(1 \rightarrow 4)$ glucose & 0 \\
\hline
\end{tabular}
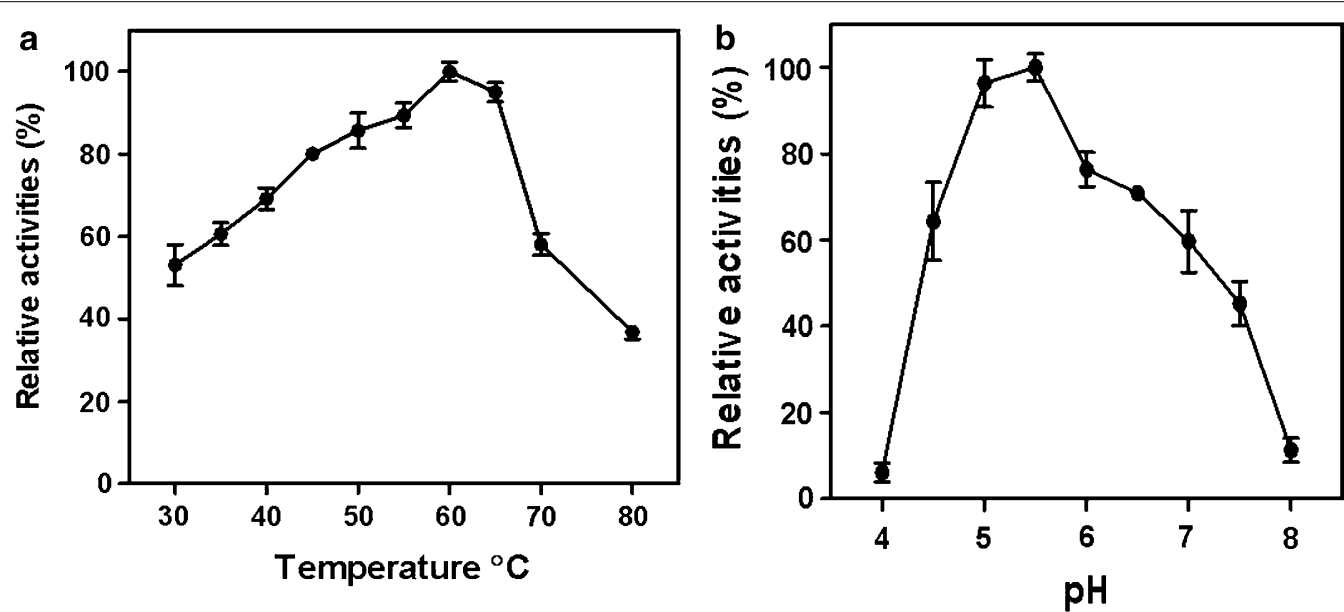

Fig. 2 The effects of $\mathrm{pH}$ and temperature on the activity of the purified NFAmy13A. a The effect of temperature on the activity of NFAmy13A was determined by incubation of $40 \mathrm{nM}$ NFAmy $13 \mathrm{~A}$ and $5 \mathrm{mg} / \mathrm{ml}$ potato starch at 5.5 at temperatures ranging from 30 to $80^{\circ} \mathrm{C}$. $\mathbf{b}$ The effect of pH on the activity of NFAmy13A was determined by incubating 40 nM NFAmy $13 \mathrm{~A}$ with $5 \mathrm{mg} / \mathrm{ml}$ potato starch between pH 4.0 and 9.0 (50 mM citrate buffer for $\mathrm{pH}$ 4.0-6.0, $50 \mathrm{mM}$ sodium phosphate buffer for $\mathrm{pH}$ 6.0-8.0, $50 \mathrm{mM}$ Tris-HCl for pH 8.0-9.0) at $55^{\circ} \mathrm{C}$. The concentration of reducing ends was estimated using the $\mathrm{pHBAH}$ assay. All values are expressed as percentages of the highest activity at one detected conditions 
than on amylose, and the activities on other starch substrates, i.e., potato starch, wheat starch, corn starch, maltodextrin, and white dextrin, were between those on amylopectin and amylose. Meanwhile, NFAmy13A also showed some activities on substrates of pullulan and glycogen. Therefore, the specificity activity was determined as $200.4 \mathrm{U} / \mathrm{mg}$ when using amylopectin as substrate.

The activity of NFAmy13A is influenced by the presence of external factors such as cations and additives. As shown in Table 2, at lower concentration of $1 \mathrm{mM}$, all of metal salts and additives did not show any effects on the activity of NFAmy13A, except $\mathrm{Hg}^{2+}, \mathrm{Co}^{2+}$ and SDS,

Table 2 Effects of different metal salts and chemical additives on activity of NFAmy13A

\begin{tabular}{|c|c|c|}
\hline \multirow[t]{2}{*}{ Additives } & \multicolumn{2}{|c|}{ Relative activity (\%) } \\
\hline & $1 \mathrm{mM}$ & $10 \mathrm{mM}$ \\
\hline a-Amylase (no additives) & $100.0 \pm 2.5$ & $100.0 \pm 1.1$ \\
\hline $\mathrm{CaCl}_{2}$ & $98.1 \pm 1.1$ & $147.5 \pm 5.1$ \\
\hline $\mathrm{AlCl}_{3}$ & $96.4 \pm 5.0$ & $98.9 \pm 5.1$ \\
\hline $\mathrm{BaCl}_{2}$ & $94.3 \pm 3.2$ & $90.8 \pm 2.7$ \\
\hline $\mathrm{CoCl}_{2}$ & $64.6 \pm 0.8$ & $47.5 \pm 3.9$ \\
\hline $\mathrm{FeCl}_{3}$ & $93.2 \pm 1.7$ & $81.1 \pm 5.9$ \\
\hline $\mathrm{CuCl}_{2}$ & $95.0 \pm 0.6$ & $83.9 \pm 0.0$ \\
\hline $\mathrm{KCl}$ & $97.7 \pm 0.9$ & $95.7 \pm 0.5$ \\
\hline $\mathrm{MgSO}_{4}$ & $95.5 \pm 2.8$ & $115.8 \pm 3.2$ \\
\hline $\mathrm{ZnSO}_{4}$ & $97.2 \pm 0.4$ & $90.9 \pm 1.4$ \\
\hline $\mathrm{NiSO}_{4}$ & $95.0 \pm 2.6$ & $84.2 \pm 5.4$ \\
\hline $\mathrm{MnSO}_{4}$ & $94.4 \pm 2.0$ & $92.3 \pm 1.4$ \\
\hline $\mathrm{HgCl}_{2}$ & $49.0 \pm 4.4$ & $2.2 \pm 0.6$ \\
\hline EDTA & $97.8 \pm 0.8$ & $87.2 \pm 3.9$ \\
\hline SDS & $80.0 \pm 3.7$ & $61.7 \pm 6.7$ \\
\hline
\end{tabular}

which showed some inhibitions. Meanwhile, at higher concentration of $10 \mathrm{mM}, \mathrm{Ca}^{2+}$ significantly stimulated the activity of NFAmy13A with $47 \%$ enhancement, and $\mathrm{Mg}^{2+}$ slightly stimulated its activity, which might suggest the enzyme needs a cofactor for its maximum activity. Among the cations and additives tested, $10 \mathrm{mM} \mathrm{Hg}^{2+}$ largely inhibited amylase activity. Under the same concentrations of $10 \mathrm{mM}, \mathrm{Co}^{2+}$ and SDS inhibited 50 and $40 \%$ of amylase activity, respectively; $\mathrm{Fe}^{2+}, \mathrm{Ni}^{2+}, \mathrm{Cu}^{2+}$ and EDTA between 10 and 20\%, while other cautions had little effect on alpha-amylase activity.

The temperature of NF liquor starter at N3 stage is $62{ }^{\circ} \mathrm{C}$, thus, the thermostable amylases are of great importance for starch hydrolysis. The thermal stability of NFAmy13A was detected at 50,60 and $70{ }^{\circ} \mathrm{C}$ in the presence and absence of $10 \mathrm{mM} \mathrm{CaCl}_{2}$, and the thermostability was positively affected by $10 \mathrm{mM} \mathrm{Ca}^{2+}$ (Fig. 3). At low temperature of $50{ }^{\circ} \mathrm{C}$, NFAmy13A was very stable with almost $100 \%$ residual activities after incubated for $16 \mathrm{~h}$. Interesting, at $60{ }^{\circ} \mathrm{C}$, the activity of NFAmy13A dropped to $28 \%$ after $3 \mathrm{~h}$, while in the presence of $\mathrm{CaCl}_{2}$ enzyme retained $100 \%$ activity after the same incubation time. Moreover, at $70{ }^{\circ} \mathrm{C}$, the activity dropped to $24 \%$ after $40 \mathrm{~min}$, and enzyme kept $57 \%$ activity after the same incubation time. The half-lives at 60 and $70{ }^{\circ} \mathrm{C}$ were improved significantly from 1.5 and $0.4 \mathrm{~h}$ to 16 and $0.7 \mathrm{~h}$, respectively, in the presence of $10 \mathrm{mM} \mathrm{CaCl}_{2}$.

As shown in Fig. 4, the kinetics hydrolysis of several starch substrates by NFAmy13A did not fit to a Michaelis-Menten equation, and velocities reached the highest point on substrates amylopectin and amylose when the concentration was $15 \mathrm{mg} / \mathrm{ml}$. NFAmy13A showed the highest values of velocity on amylopectin and the lowest values on amylose, while the velocities on potato starch, wheat starch and corn starch were in middle at

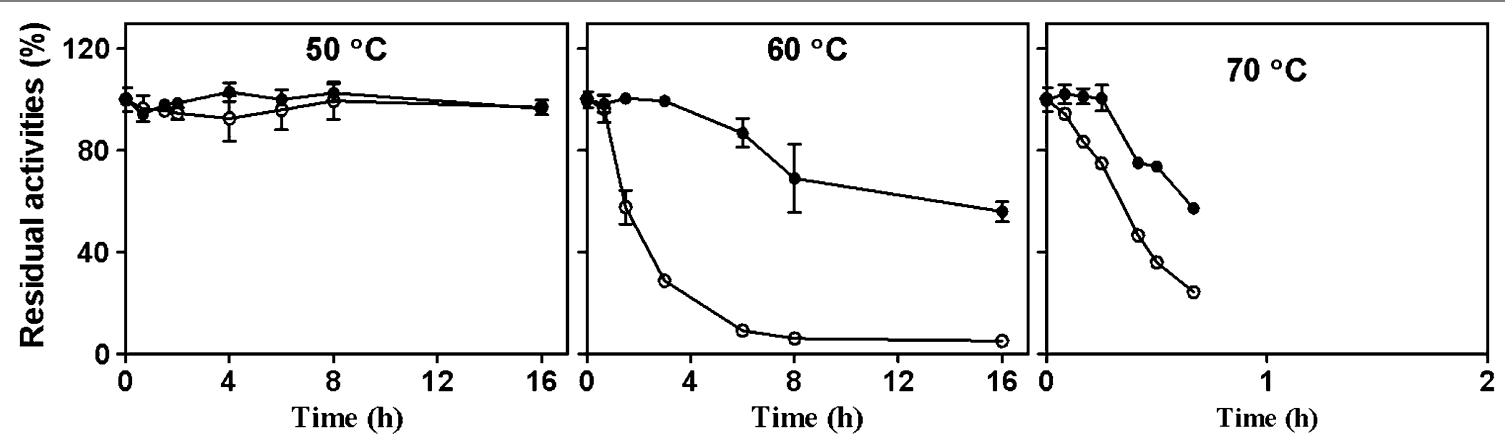

$\mathrm{O}$ : without $10 \mathrm{mM} \mathrm{CaCl}_{2} / \mathbf{0}$ : with $10 \mathrm{mM} \mathrm{CaCl}_{2}$

Fig. 3 The effect of temperature on the stability of the NFAmy 13 A. The enzyme $(80 \mathrm{nM})$ was incubated in a citrate buffer $(\mathrm{pH} 5.5)$ at 50,60 and $70{ }^{\circ} \mathrm{C}$ for different times in the presence (filled circle) or absence (circle) of $10 \mathrm{mM} \mathrm{CaCl}_{2}$. The residual enzymatic activity was determined by incubating $40 \mathrm{nM}$ enzymes with $5 \mathrm{mg} / \mathrm{ml}$ amylopectin at $60^{\circ} \mathrm{C}$ in a citrate buffer $(\mathrm{pH} \mathrm{5.5)} \mathrm{for} 30 \mathrm{~min}$. All values are expressed as percentages of the activity of untreated enzyme 


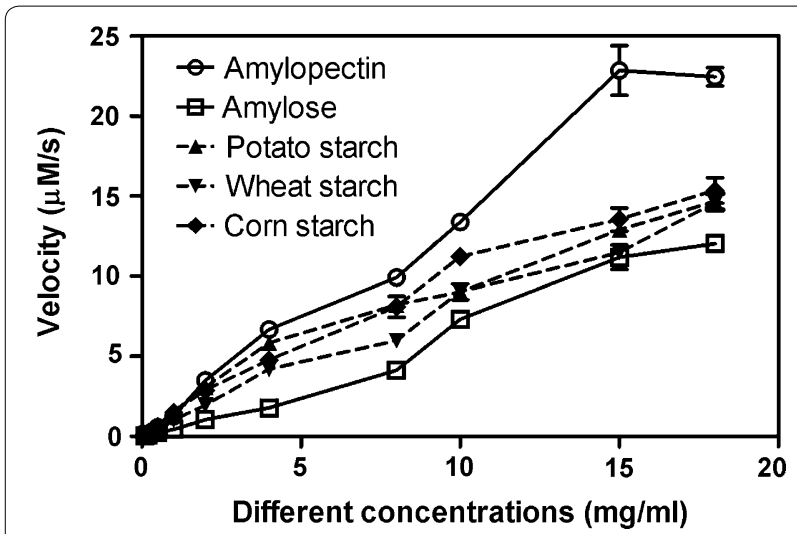

Fig. 4 Kinetics hydrolysis of NFAmy13A on starch substrates. The purified NFAmy13A (20 nM) was incubated with different concentrations $(0.1-18 \mathrm{mg} / \mathrm{ml})$ of starch substrates, i.e., amylopectin, amylose, potato starch, corn starch or wheat starch, for $30 \mathrm{~min}$ in the presence of $10 \mathrm{mM} \mathrm{CaCl}_{2}$ all detecting concentrations of substrates. Those results were similar as observed in Table 2.

\section{Application of NFAmy13A in the hydrolysis of starch substrates}

To mimic the hydrolysis of wheat starch in liquor starter, starch substrates were completely dissolved in warm buffer $\left(60-80{ }^{\circ} \mathrm{C}\right.$ ), and varied concentrations (from 1 to $18 \mathrm{mg} / \mathrm{ml}$ ) of substrates were hydrolyzed with a constant enzyme dose $(1 \mu \mathrm{M})$. As shown in Fig. $5 \mathrm{a}$, at the same enzyme concentration, increasing any of the three substrates led to release of more products. The releasing reducing sugars reached the highest values at high concentration of $15 \mathrm{mg} / \mathrm{ml}$ for all three substrates, and more reducing sugars were released from potato starch than wheat starch and corn starch. The main end products for all three substrates were maltose, and small amounts of glucose were released throughout most of the conditions
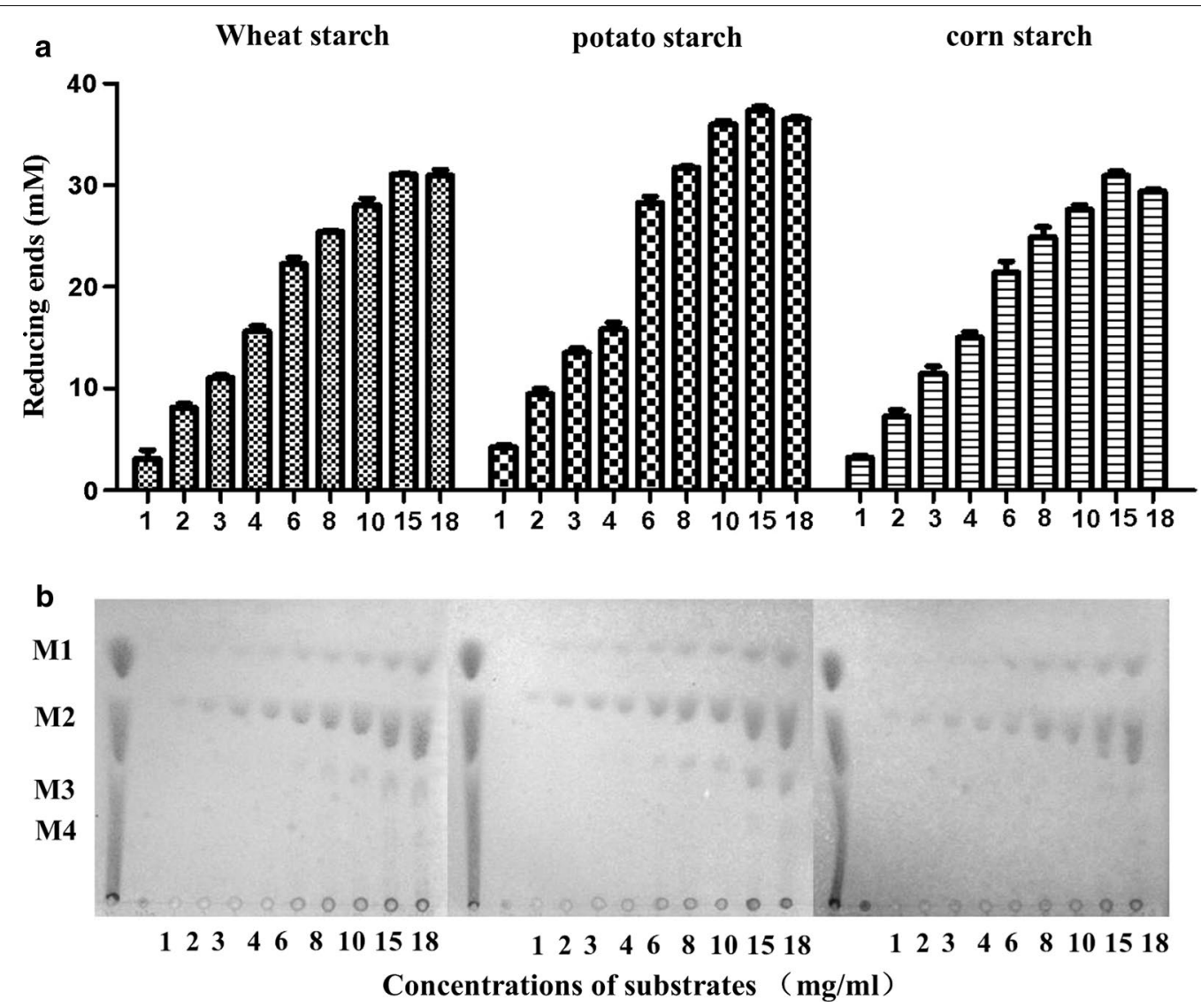

Fig. 5 Hydrolysis of increasing amounts of starch substrates by NFAmy13A. The products were analyzed by both reducing sugar assay (a) and TLC analysis (b). Different concentrations (1-18 mg/ml) of potato starch, corn starch or wheat starch were incubated with $1 \mu \mathrm{M}$ enzymes in the presence of $10 \mathrm{mM} \mathrm{CaCl}$ at $\mathrm{pH} 5.5$ and $60^{\circ} \mathrm{C}$ for $20 \mathrm{~h}$. M1, glucose; M2, maltose; M3, maltotriose; M4, maltotetraose 
(Fig. 5b). Minor maltotriose was also clearly detected at concentration of 15 and $18 \mathrm{mg} / \mathrm{ml}$ substrates. More glucose and maltose-oligosaccharides were detected at higher concentration of substrates, and more were released from potato starch and wheat starch than from corn starch.

\section{Discussion}

NF liquor starter is enriched with special and stable microbial communities after several 1000 years' evolution, and plenty of active enzymes are found with efficient capacity in degrading carbohydrates and protein. However, in a pretty long time, few active enzymes were mined and characterized from NF liquor starter by traditional culture based methods. Recently, our previous metatranscriptomic study on NF liquor starter might provide a direct and easy sequence-based method to mine those functional enzymes and understand their roles in NF liquor brewing. Among these enzymes, $\alpha$-amylases play a pivotal role in the liquefaction of starch, and thermostable $\alpha$-amylases gains more attentions due to their potential applications at a high operation temperature $\left(>60{ }^{\circ} \mathrm{C}\right)$ compared to mesophilic $\alpha$-amylases. Therefore, this study was performed to verify the feasibility of directly mining enzymes from NF liquor starter, and a thermostable $\alpha$-amylase (NFAmy13A) was successfully obtained from high temperature period (N3).

Protein sequence analysis showed that NFAmy13A had a signal peptide and, without signal peptide, it shared the highest sequence identity of $64 \%$ with $\alpha$-amylase (crystal structure: 2GUY-A) from Aspergillus niger, thus possibly originating from a fungal genus. As we know, fungal $\alpha$-amylases are more preferred for starch hydrolysis in traditional food industries, e.g., brewing (Chinese liquor, wheat wine, soy sauce and vinegar), baking and sweeteners, and pharmaceutical industries due to their nontoxic characteristics $[8,18,19]$. In addition, three catalytic sites (Asp206, Glu230, Asp297) in 2GUY-A were also conserved in NFAmy13A (Asp208, Glu232, Asp299) (Fig. 6), so NFAmy13A might have same hydrolysis reaction [20]. Moreover, most of the reported fungal $\alpha$-amylases were native proteins (Table 3 ), and only a few were heterologously expressed in E. coli [21], Aspergillus oryzae [22], P. pastoris [23-26], or Saccharomyces cerevisiae [27].

Similar to most of fungal $\alpha$-amylases, NFAmy13A had acidic $\mathrm{pH}$ optima at $<5.5$ (Table 3 ), which is preferred in starch industries [28-30]. On the contrary, some fungal $\alpha$-amylases showed high $\mathrm{pH}$ optima at $>7.0[26,31,32]$, which could be used in detergent industry. As shown in Table 3, most of fungal $\alpha$-amylases are unable to work at temperatures more than $50-60{ }^{\circ} \mathrm{C}$. Meanwhile, NFAmy13A had an optimum temperature at $60{ }^{\circ} \mathrm{C}$ and was stable with half-life of $1.5 \mathrm{~h}$ at $60{ }^{\circ} \mathrm{C}$. Similar or higher thermostabilities were also found in a few fungal amylases from Aspergillus niveus [33], Paecilomyces variotii [34], Rhizomucor pusillus [25], Streptomyces megasporus [35] and Thermomyces lanuginosus [36]. Thermostable fungal $\alpha$-amylases are mostly used in the starch hydrolysis of baking and brewing industries [8, 37].

Among the cation and additives tested, $10 \mathrm{mM} \mathrm{Hg}^{2+}$ largely inhibited NFAmy13A activity, which has been well observed on some fungal alpha-amylases [33, 35, 38-42]. The stimulation of $\mathrm{Ca}^{2+}$ was also found in other fungal alpha-amylases [22, 31-34, 43-48]. The 'high-affinity' $\mathrm{Ca}^{2+}$-binding sites (Asn121, Glu162, Asp175, His210) in 2GUY-A were highly conserved in NFAmy13A (Asn123, Glu164, Asp177, His212) (Fig. 6), indicating that NFAmy13A was a metalloenzyme and strongly bound $\mathrm{Ca}^{2+}$. Similar as some $\alpha$-amylases reported previously [22, 30,

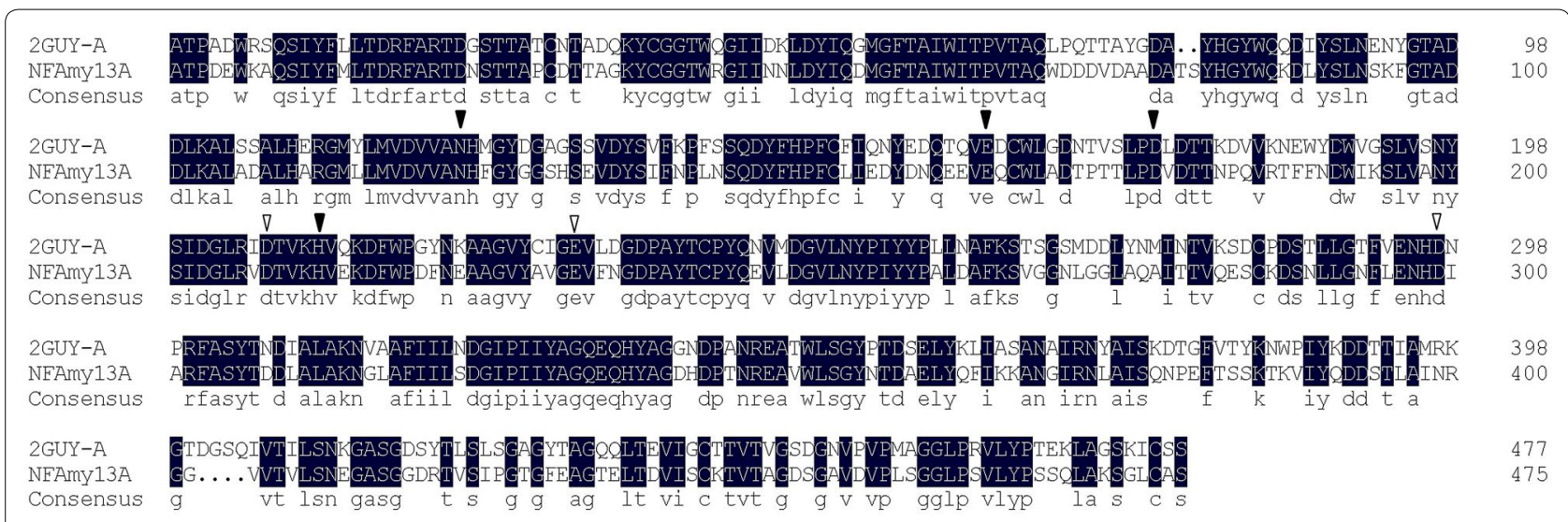

Fig. 6 Protein sequences alignment between NFAmy13A and a-amylase (crystal structure: 2GUY-A) from Aspergillus niger. The conserved catalytic sites were highlighted with 'inverted triangle', and the conserved $\mathrm{Ca}^{2+}$-binding sites were highlighted with 'filled inverted triangle' 


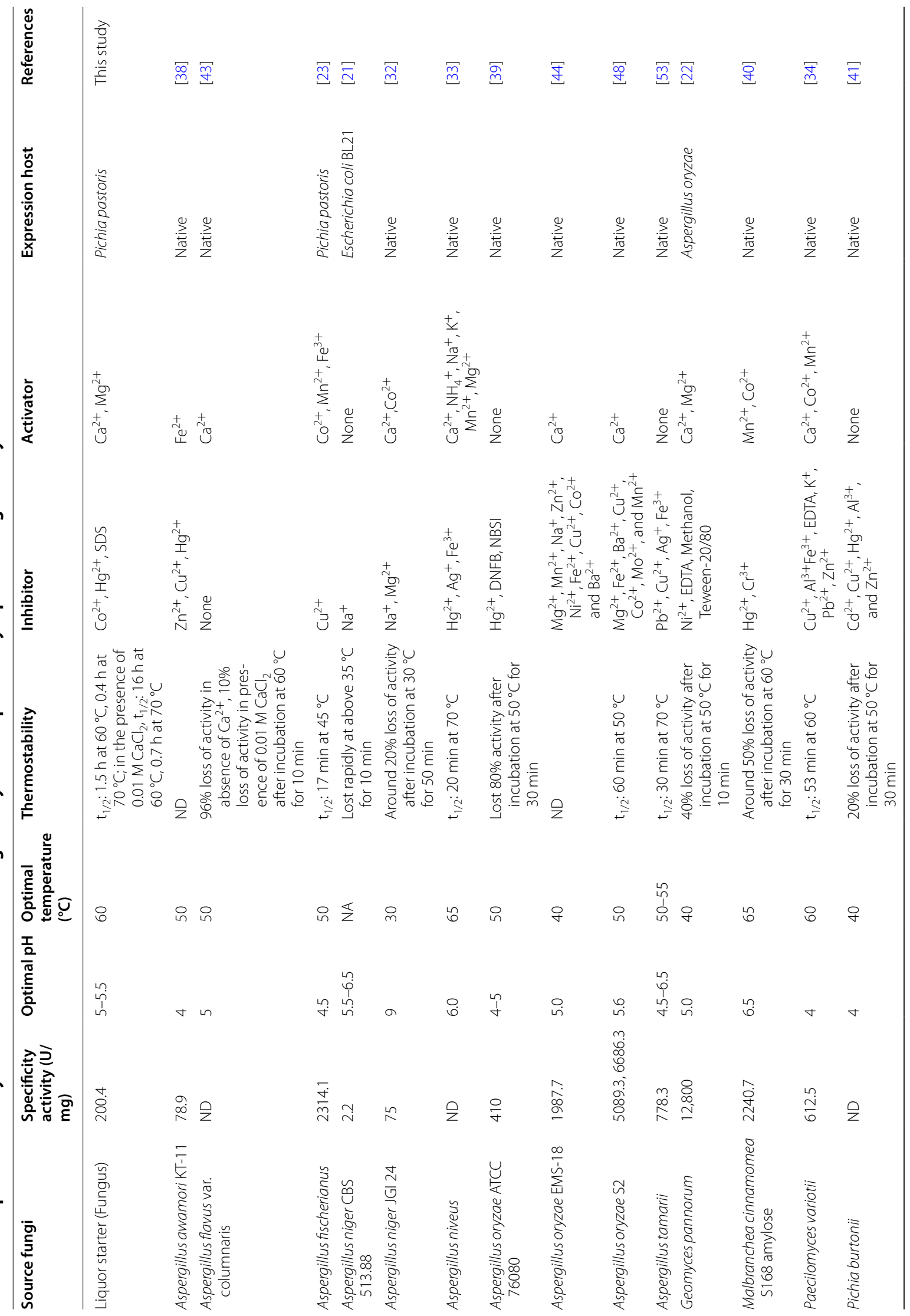




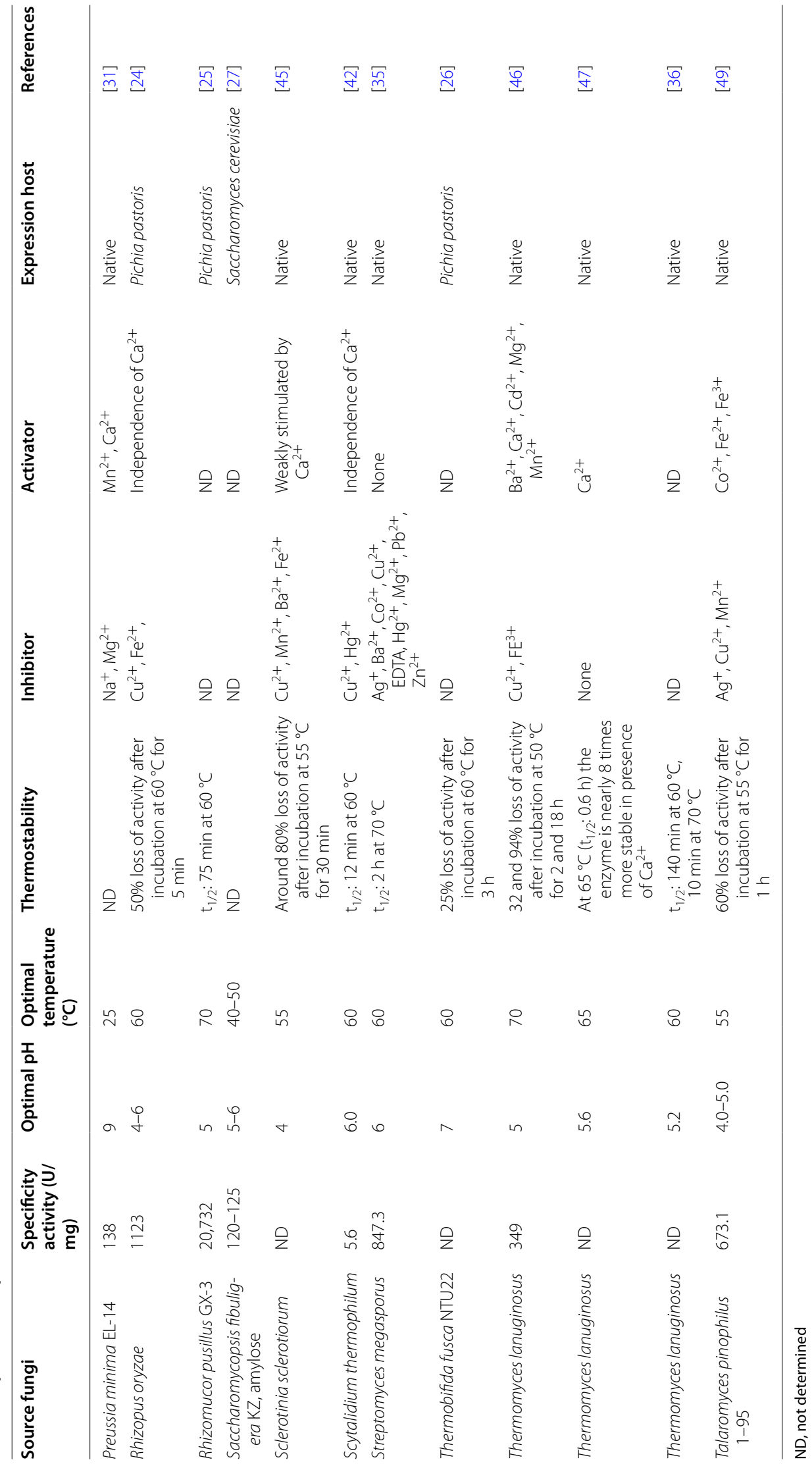


33, 49], NFAmy13A was insensitive to EDTA, and one of the possible reason might be that the affinity of calcium to NFAmy13A was stronger than that of EDTA. Moreover, the stabilizing effect of $\mathrm{Ca}^{2+}$ on thermostability was observed in NFAmy13A, which might be explained due to the formation of a calcium-sodium-calcium metal triad in the main $\mathrm{Ca}^{2+}$-binding site of the enzyme [50], and has also been found in some fungal alpha-amylases $[43,47]$.

As shown in Table 1 and Fig. 4, NFAmy13A showed the maximum activity on amylopectin, followed by starch, amylose, glycogen, and pullulan at all detected concentrations, and its specificity activity on amylopectin was $200.4 \mathrm{U} / \mathrm{mg}$, which was within the range values of the reported fungal $\alpha$-amylases (Table 3 ). In general, amylopectin has $\alpha-1,4$ glycosidic bond in the main chain and $\alpha-1,6$ glycosidic bond in the branching chain, resulting in many end points onto which enzymes can easily attach. Meanwhile, amylose only has $\alpha-1,4$ glycosidic bond in the main chain and forms tightly packed helical structure. Possibly, their structural differences were one of the reasons that NFAmy13A was more efficient to degrade amylopectin than amylose. This preference of NFAmy13A on amylopectin further verified its important role in NF liquor starter, since wheat material of NF liquor starter has higher amylopectin content of its starch than its amylose content [51]. Moreover, this preference of NFAmy13A potentially enhance its pivotal role in the following stage of alcohol fermentation, because the main material of alcohol fermentation is sorghum [8] and sorghum also has higher amylopectin content [52]. Similar preference between amylopectin and amylose was also found in other fungus $\alpha$-amylase [22, 25]. Whereas, some fungal amylases showed higher activity on amylose than on amylopectin [21, 40, 49, 53]. Similar as amylopectin, glycogen is also composed with main chain of $\alpha-1,4$ glycosidic bond and side chain of $\alpha-1,6$ glycosidic bond, but being more branched and compact. This might be the reason that NFAmy13A could catalyze glycogen effectively and the degradation efficiency on glycogen is lower than that on amylopectin, which was also observed in other fungal $\alpha$-amylases [22, 25, 48]. In addition, NFAmy13A exhibited very low activity toward pullulan, which perhaps resulted from the resistant structure that maltotriose ( $\alpha-1,4$ glycosidic bond) unites are connected to each other by $\alpha-1,6$ glycosidic bond in pullulan. Most other fungal $\alpha$-amylases also showed weak activity toward pullulan $[22,48,49,53]$, except for fungal $\alpha$-amylase from Malbranchea cinnamomea, which showed high activity on pullulan [40].

NFAmy13A showed high activity toward soluble starches from corn, wheat, and potato, and worked efficiently at high concentrations up to $15 \mathrm{mg} / \mathrm{ml}$. Its end products were maltose, glucose and minor maltotriose. Among them, main products of maltose and glucose can be easily uptake by yeast in the following alcohol fermentation stage, which further verified its pivotal role in the liquor fermentation. Therefore, as shown in Table 3, compared with other fungal $\alpha$-amylases, NFAmy13A showed some advantageous characteristics in hydrolyzing starch substrates, e.g., high thermostability at $60{ }^{\circ} \mathrm{C}$, acidic $\mathrm{pH}$ optima at 5.0-5.5, $\mathrm{Ca}^{2+}$-dependent, high activity on wheat starch, the more efficient hydrolysis on amylopectin than on amylose, and tolerances at high substrates concentrations $(15 \mathrm{mg} / \mathrm{ml})$, which to some extent proved previous finding that NFAmy13A was the highest expressed $\alpha$-amylase at $62{ }^{\circ} \mathrm{C}$ and relatively high expressed $\alpha$-amylase at mature stage in NF liquor starter, thus being the largest contribution in liquefying starch into glucose and maltose at solid state at high temperature stage and mature stage [3]. Moreover, as we know, corn and wheat, are also widely used for fuel ethanol production [54], and high activity toward corn and wheat highlights the potential applications of NFAmy13A in ethanol industrial. In addition, taking into account the safe advantage of fungal $\alpha$-amylase, NFAmy13A was a good candidate in starch hydrolysis in food and pharmaceutical industries.

\section{Conclusions}

A direct and efficient sequence-based method of metatranscriptomics is provided to mine active enzymes from NF liquor starter in present work. And by this way, a thermostable fungal $\alpha$-amylase (NFAmy13A) gene is successfully obtained from environmental cDNA library of NF liquor starter, and expressed in P. pastoris. The recombinant enzyme of NFAmy13A has optimal $\mathrm{pH}$ of $5.0-5.5$ and optimal temperature as high as $60^{\circ} \mathrm{C}$. When compared with other fungal $\alpha$-amylases, NFAmy13A shows interesting characteristics, such as high thermostability, $\mathrm{Ca}^{2+}$-dependent on activity and thermostability, high activity on amylopectin, starches (from corn, wheat, and potato), amylose and glycogen, the more efficient hydrolysis on amylopectin than on amylose, and tolerances of high substrates concentrations. Therefore, NFAmy13A not only plays pivotal role in the solid-state SSF of starch liquefaction in NF liquor brewing, but also has potential application in the solid-state SSF process of other food industries, and pharmaceutical industries. Successfully mining $\alpha$-amylase (NFAmy13A) from NF liquor starter will stimulate the characterization of more enzymes related to polysaccharides degradation in future, such as starch, cellulose, and hemicellulose. Their synergistic roles in degrading polysaccharides in liquor starter will also be studied, thus paving the way toward the optimization of liquor production and improvement 
of liquor quality, and stimulating potential application as safe additive for other industrial applications, such as bioenergy production, food or feed preservation and high valued-added products.

\section{Additional file}

Additional file 1. Additional tables.

\section{Authors' contributions}

$\mathrm{ZY}, \mathrm{HZ}, \mathrm{YJ}, \mathrm{KH}, \mathrm{DL}, \mathrm{HL}$ and YF designed the experiment; $\mathrm{ZY}, \mathrm{DZ}$ and $\mathrm{HH}$ collected liquor starter samples; $Z Y$ performed the experiment and analyzed data; $Z Y$ wrote the main manuscript; $Z Y, Y J$ and $\mathrm{HZ}$ revised the manuscript. All authors read and approved the final manuscript.

\section{Author details}

${ }^{1}$ Meat-processing Application Key Laboratory of Sichuan Province, College of Pharmacy and Biological Engineering, Chengdu University, Chengdu, China. ${ }^{2}$ Key Laboratory of Environmental and Applied Microbiology, Chinese Academy of Sciences, Chengdu, China. ${ }^{3}$ Environmental Microbiology Key Laboratory of Sichuan Province, Chengdu Institute of Biology, Chinese Academy of Sciences, No. 9 Section 4, Renmin Nan Road, Chengdu 610041. Sichuan, People's Republic of China. ${ }^{4}$ Liquor Making Bio-Technology \& Application of Key Laboratory of Sichuan Province, Bioengineering College, Sichuan University of Science \& Engineering, Zigong, China. ${ }^{5}$ Wuliangye Group, Yibin, China. ${ }^{6}$ Department of Liquor Making Engineering, Moutai College, Renhuai, China.

\section{Acknowledgements}

We thank Professors Zhongyan Wang for providing valuable suggestions concerning liquor starter research.

\section{Competing interests}

The authors declare that they have no competing interests.

\section{Availability of data and materials}

All the data generated or analyzed during this study have been included in this published article.

\section{Ethics approval and consent to participate}

This study does not contain any experiment with human participants or animals performed by any of the authors.

\section{Funding}

This study was supported by China Agriculture Research System (CARS10-B22): the National Key Technology R\&D Program of China (No. 2015BAD15B01); the National Natural Science for Youth Foundation of China (Nos. 31400685 and 21606218); the National Natural Science for General Foundation of China (No. 31770395); Science \& Technology Program of Sichuan Province (2017NZ0018 and 2017HH0077); Key Laboratory of Environmental and Applied Microbiology, Chengdu Institute of Biology, Chinese Academy of Sciences (Nos. KLEAMCAS201501, KLCAS-2016-02 and KLCAS-2016-06).

\section{Publisher's Note}

Springer Nature remains neutral with regard to jurisdictional claims in published maps and institutional affiliations.

Received: 28 September 2017 Accepted: 12 February 2018

Published online: 22 February 2018

\section{References}

1. Xu ML, Yu Y, Ramaswamy HS, Zhu SM. Characterization of Chinese liquor aroma components during aging process and liquor age discrimination using gas chromatography combined with multivariable statistics. Sci Rep. 2017;7:39671.

2. Xiao D, Zhao S, Chen Y, Du L. Baijiu manufacturing technology. Beijing: Chemical Industry Press; 2011. p. 2.

3. Huang $Y$, Yi Z, Jin Y, Huang M, He K, Liu D, Luo H, Zhao D, He H, Fang Y, Zhao H. Metatranscriptomics reveals the functions and enzyme profiles of the microbial community in Chinese Nong-flavor liquor starter. Front Microbiol. 2017:8:1747.

4. Chen B, Wu Q, Xu Y. Filamentous fungal diversity and community structure associated with the solid state fermentation of Chinese Maotai-flavor liquor. Int J Food Microbiol. 2014;179:80-4.

5. Huang Y, Yi Z, Jin Y, Zhao Y, He K, Liu D, Zhao D, He H, Luo H, Zhang W, et al. New microbial resource: microbial diversity, function and dynamics in Chinese liquor starter. Sci Rep. 2017;7:14577.

6. Wang $X, D u H, X u$ Y. Source tracking of prokaryotic communities in fermented grain of Chinese strong-flavor liquor. Int J Food Microbiol. 2017;244:27-35.

7. Liu J, Chen J, Fan Y, Huang X, Han B. Biochemical characterization and dominance of different hydrolases in different types of Daqu-a Chinese industrial fermentation starter. J Sci Food Agric. 2018;98:113-21.

8. Xu Y, Wang D, Fan WL, Mu XQ, Chen J. Traditional Chinese biotechnology. In: Tsao GT, Ouyang P, Chen J, editors. Biotechnology in China II: chemicals, energy and environment. Berlin: Springer; 2010. p. 189-233.

9. Ufarté L, Potocki-Veronese G, Laville É. Discovery of new protein families and functions: new challenges in functional metagenomics for biotechnologies and microbial ecology. Front Microbiol. 2015;6:563.

10. Sethi A, Slack JM, Kovaleva ES, Buchman GW, Scharf ME. Lignin-associated metagene expression in a lignocellulose-digesting termite. Insect Biochem Mol Biol. 2013;43:91-101.

11. Findley SD, Mormile MR, Sommer-Hurley A, Zhang X-C, Tipton P, Arnett K, Porter JH, Kerley M, Stacey G. Activity-based metagenomic screening and biochemical characterization of bovine ruminal protozoan glycoside hydrolases. Appl Environ Microbiol. 2011;77:8106-13.

12. Damon C, Vallon L, Zimmermann S, Haider MZ, Galeote V, Dequin S, Luis P, Fraissinet-Tachet L, Marmeisse R. A novel fungal family of oligopeptide transporters identified by functional metatranscriptomics of soil eukaryotes. ISME J. 2011:5:1871-80.

13. Bailly J, Fraissinet-tachet L, Verner M, Debaud J, Lemaire M, Wésolowskilouvel M, Marmeisse R. Soil eukaryotic functional diversity, a metatranscriptomic approach. ISME J. 2007;1:632-42.

14. Takasaki K, Miura T, Kanno M, Tamaki H, Hanada S, Kamagata Y, Kimura $N$. Discovery of glycoside hydrolase enzymes in an avicel-adapted forest soil fungal community by a metatranscriptomic approach. PLOS ONE. 2013:8:e55485

15. Mozhaev VV. Mechanism-based strategies for protein thermostabilization. Trends Biotechnol. 1993;11:88-95.

16. Lever M. A new reaction for colorimetric determination of carbohydrates. Anal Biochem. 1972;47:273-9.

17. Moon YH, lakiviak M, Bauer S, Mackie RI, Cann IKO. Biochemical analyses of multiple endoxylanases from the rumen bacterium Ruminococcus albus 8 and their synergistic activities with accessory hemicellulosedegrading enzymes. Appl Environ Microbiol. 2011;77:5157-69.

18. El-Okki AKEH, Gagaoua M, Bourekoua H, Hafid K, Bennamoun L, DjekrifDakhmouche S, El-Hadef El-Okki M, Meraihi Z. Improving bread quality with the application of a newly purified thermostable a-amylase from Rhizopus oryzae FSIS4. Foods. 2017;6:1.

19. Kim JH, Maeda T, Morita N. Effect of fungal a-amylase on the dough properties and bread quality of wheat flour substituted with polished flours. Food Res Int. 2006;39:117-26.

20. Vujičić-Žagar A, Dijkstra BW. Monoclinic crystal form of Aspergillus niger a-amylase in complex with maltose at $1.8 \AA$ resolution. Acta Crystallogr Sect F Struct Biol Cryst Commun. 2006;62:716-21.

21. van der Kaaij RM, Janeček Š, van der Maarel MJEC, Dijkhuizen L. Phylogenetic and biochemical characterization of a novel cluster of intracellular fungal a-amylase enzymes. Microbiology. 2007;153:4003-15.

22. He L, Mao Y, Zhang L, Wang H, Alias SA, Gao B, Wei D. Functional expression of a novel a-amylase from Antarctic psychrotolerant fungus for baking industry and its magnetic immobilization. BMC Biotechnol. 2017;17:22. 
23. Xiao Z, Wu M, Grosse S, Beauchemin M, Lévesque M, Lau PCK. Genome mining for new a-amylase and glucoamylase encoding sequences and high level expression of a glucoamylase from Talaromyces stipitatus for potential raw starch hydrolysis. Appl Biochem Biotechnol. 2014;172:73-86.

24. Li S, Zuo Z, Niu D, Singh S, Permaul K, Prior BA, Shi G, Wang Z. Gene cloning, heterologous expression, and characterization of a high maltoseproducing a-amylase of Rhizopus oryzae. Appl Biochem Biotechnol. 2011;164:581-92.

25. He Z, Zhang L, Mao Y, Gu J, Pan Q, Zhou S, Gao B, Wei D. Cloning of a novel thermostable glucoamylase from thermophilic fungus Rhizomucor pusillus and high-level co-expression with a-amylase in Pichia pastoris. BMC Biotechnol. 2014;14:114.

26. Yang $\mathrm{C}-\mathrm{H}$, Huang $\mathrm{Y}-\mathrm{C}$, Chen $\mathrm{C}-\mathrm{Y}$, Wen $\mathrm{C}-\mathrm{Y}$. Expression of Thermobifida fusca thermostable raw starch digesting alpha-amylase in Pichia pastoris and its application in raw sago starch hydrolysis. J Ind Microbiol Biotechnol. 2010;37:401-6.

27. Hostinová E, Janeček Š, Gašperík J. Gene sequence, bioinformatics and enzymatic characterization of a-amylase from Saccharomycopsis fibuligera KZ. Protein J. 2010:29:355-64.

28. Presečki AV, Blažević ZF, Vasić-Rački Đ. Complete starch hydrolysis by the synergistic action of amylase and glucoamylase: impact of calcium ions. Bioprocess Biosyst Eng. 2013;36:1555-62.

29. Liu XD, Xu Y. A novel raw starch digesting a-amylase from a newly isolated Bacillus sp. YX-1: purification and characterization. Bioresour Technol. 2008;99:4315-20.

30. Sajedi RH, Naderi-Manesh H, Khajeh K, Ahmadvand R, Ranjbar B, Asoodeh A, Moradian F. A Ca-independent a-amylase that is active and stable at low pH from the Bacillus sp. KR-8104. Enzyme Microb Technol. 2005;36:666-71.

31. Zaferanloo B, Bhattacharjee S, Ghorbani MM, Mahon PJ, Palombo EA. Amylase production by Preussia minima, a fungus of endophytic origin: optimization of fermentation conditions and analysis of fungal secretome by LC-MS. BMC Microbiol. 2014;14:55.

32. Varalakshmi K, Kumudini B, Nandini B, Solomon J, Suhas R, Mahesh B, Kavitha A. Production and characterization of alpha-amylase from Aspergillus niger JGI 24 isolated in Bangalore. Pol J Microbiol. 2009;58:29-36.

33. Silva TM, Damásio ARdL, Maller A, Michelin M, Squina FM, Jorge JA, Polizeli MdLTdM. Purification, partial characterization, and covalent immobilization-stabilization of an extracellular a-amylase from Aspergillus niveus. Folia Microbiol (Praha). 2013;58:495-502.

34. Michelin M, Silva TM, Benassi VM, Peixoto-Nogueira SC, Moraes LAB, Leão JM, Jorge JA, Terenzi HF, Polizeli MdLTM. Purification and characterization of a thermostable a-amylase produced by the fungus Paecilomyces variotii. Carbohydr Res. 2010;345:2348-53.

35. Dey S, Agarwal SO. Characterization of a thermostable alpha-amylase from a thermophilic Streptomyces megasporus strain SD12. Indian J Biochem Biophys. 1999;36:150-7.

36. Jensen B, Olsen J. Physicochemical properties of a purified alpha-amylase from the thermophilic fungus Thermomyces lanuginosus. Enzyme Microb Technol. 1992;14:112-6.

37. Prakash O, Jaiswal N. a-Amylase: an ideal representative of thermostable enzymes. Appl Biochem Biotechnol. 2010;160:2401-14.

38. Anindyawati T, Melliawati R, Ito K, lizuka M, Minamiura N. Three different types of a-amylases from Aspergillus awamori KT-11: their purifications, properties, and specificities. Biosci Biotechnol Biochem. 1998;62:1351-7.

39. Chang C, Tang M. CF L: purification and properties of alpha-amylase from Aspergillus oryzae ATCC 76080. Biochem Mol Biol Int. 1995;36:185-93.

40. Han P, Zhou P, Hu S, Yang S, Yan Q, Jiang Z. A novel multifunctional a-amylase from the thermophilic fungus Malbranchea cinnamomea: biochemical characterization and three-dimensional structure. Appl Biochem Biotechnol. 2013;170:420-35.

41. Takeuchi A, Shimizu-Ibuka A, Nishiyama Y, Mura K, Okada S, Tokue C, Arai S. Purification and characterization of an a-amylase of Pichia burtonii isolated from the traditional starter "Murcha" in Nepal. Biosci Biotechnol Biochem. 2006;70:3019-24.

42. Aquino ACMM, Jorge JA, Terenzi HF, Polizeli MLTM. Studies on a thermostable a-amylase from the thermophilic fungus Scytalidium thermophilum. Appl Microbiol Biotechnol. 2003;61:323-8.

43. Ali F, Abdel-Moneim A. Physico-chemical properties of Aspergillus flavus var. columnaris alpha-amylase. Zentralbl Mikrobiol. 1989;144:615-21.

44. Abdullah R, kram-ul-Haq. Purification and characterisation of a-amylase produced by mutant strain of Aspergillus oryzae EMS-18. Nat Prod Res. 2015;29:710-6.

45. Ben A-K, Urdaci M, Limam F, Schmitter J, Marzouki M, Bressollier P. Purification, characterization, and partial primary sequence of a major-maltotriose-producing alpha-amylase, ScAmy43, from Sclerotinia sclerotiorum. Microbiol Biotechnol. 2008;18:1555-63.

46. Petrova SD, Ilieva SZ, Bakalova NG, Atev AP, Bhat MK, Kolev DN. Production and characterization of extracellular alpha-amylases from the thermophilic fungus Thermomyces lanuginosus (wild and mutant strains). Biotechnol Lett. 2000;22:1619-24.

47. Mishra RS, Maheshwari R. Amylases of the thermophilic fungus Thermomyces lanuginosus: their purification, properties, action on starch and response to heat. J Biosci. 1996;21:653-72.

48. Sahnoun M, Bejar S, Sayari A, Triki MA, Kriaa M, Kammoun R. Production, purification and characterization of two a-amylase isoforms from a newly isolated Aspergillus oryzae strain S2. Process Biochem. 2012;47:18-25.

49. Xian L, Wang F, Luo X, Feng Y-L, Feng J-X. Purification and characterization of a highly efficient calcium-independent a-amylase from Talaromyces pinophilus 1-95. PLoS ONE. 2015;10:e0121531.

50. Machius M, Declerck N, Huber R, Wiegand G. Activation of Bacillus licheniformis a-amylase through a disorder $\rightarrow$ order transition of the substrate-binding site mediated by a calcium-sodium-calcium metal triad. Structure. 1998:6:281-92.

51. Zhang W, Gu J, Wang Z, Wei C, Yang J, Zhang J. Comparison of structural and functional properties of wheat starch under different soil drought conditions. Sci Rep. 2017;7:12312.

52. Ai Y, Medic J, Jiang H, Wang D, Jane J-L. Starch characterization and ethanol production of sorghum. J Agric Food Chem. 2011;59:7385-92.

53. Moreira FG, Lenartovicz V, Peralta RM. A thermostable maltose-tolerant a-amylase from Aspergillus tamarii. J Basic Microbiol. 2004:44:29-35.

54. Sánchez ÓJ, Cardona CA. Trends in biotechnological production of fuel ethanol from different feedstocks. Bioresour Technol. 2008;99:5270-95.

\section{Submit your next manuscript to BioMed Central and we will help you at every step:}

- We accept pre-submission inquiries

- Our selector tool helps you to find the most relevant journal

- We provide round the clock customer support

- Convenient online submission

- Thorough peer review

- Inclusion in PubMed and all major indexing services

- Maximum visibility for your research

Submit your manuscript at www.biomedcentral.com/submit
() BioMed Central 